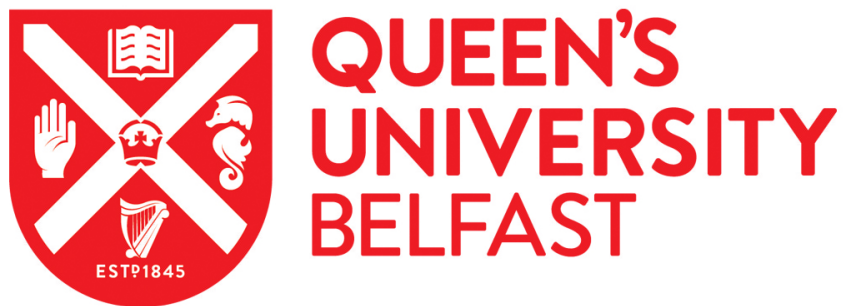

\section{Deletion of TRPC4 and TRPC6 in Mice Impairs Smooth Muscle Contraction and Intestinal Motility In Vivo.}

Tsvilovskyy, V. V., Zholos, A., Aberle, T., Philipp, S. E., Dietrich, A., Zhu, M. X., Birnbaumer, L., Freichel, M., \& Flockerzi, V. (2009). Deletion of TRPC4 and TRPC6 in Mice Impairs Smooth Muscle Contraction and Intestinal Motility In Vivo. Gastroenterology, 137(4), 1415-1424. https://doi.org/10.1053/j.gastro.2009.06.046

\section{Published in: \\ Gastroenterology}

Document Version:

Peer reviewed version

Queen's University Belfast - Research Portal:

Link to publication record in Queen's University Belfast Research Portal

\section{General rights}

Copyright for the publications made accessible via the Queen's University Belfast Research Portal is retained by the author(s) and / or other copyright owners and it is a condition of accessing these publications that users recognise and abide by the legal requirements associated with these rights.

Take down policy

The Research Portal is Queen's institutional repository that provides access to Queen's research output. Every effort has been made to ensure that content in the Research Portal does not infringe any person's rights, or applicable UK laws. If you discover content in the Research Portal that you believe breaches copyright or violates any law, please contact openaccess@qub.ac.uk. 


\title{
Deletion of TRPC4 and TRPC6 in mice impairs smooth muscle contraction and intestinal motility in vivo
}

\author{
Volodymyr V. Tsvilovskyy ${ }^{1}$, Alexander V. Zholos ${ }^{2}$, Thomas Aberle ${ }^{1}$, Stephan E. Philipp ${ }^{1}$, \\ Alexander Dietrich ${ }^{3}$, Michael X. Zhu ${ }^{4}$, Lutz Birnbaumer ${ }^{5}$, Marc Freichel ${ }^{1}$, and Veit \\ Flockerzi $^{1}$ \\ ${ }^{1}$ Experimentelle und Klinische Pharmakologie und Toxikologie, Universität des Saarlandes, 66421 \\ Homburg, Germany \\ ${ }^{2}$ Centre for Vision \& Vascular Science, School of Medicine, Dentistry and Biomedical Sciences, \\ Queens's University Belfast, 97 Lisburn Road, Belfast BT9 7BL, UK \\ ${ }^{3}$ Institut für Pharmakologie und Toxikologie, Medizinische Fakultät, Universität Marburg, 35043 \\ Marburg, Germany \\ ${ }^{4}$ Department of Neuroscience, Biochemistry, and Center for Molecular Neurobiology, The Ohio \\ State University, Columbus OH 43210, USA \\ ${ }^{5}$ Signal Transduction and Neurobiology Laboratories, Division of Intramural Research, National \\ Institute of Environmental Health Sciences, National Institutes of Health, Research Triangle Park, \\ NC 27709, USA.
}

\begin{abstract}
Background \& Aims-Downstream effects of muscarinic receptor stimulation in intestinal smooth muscle include contraction and intestinal transit. We thought to determine whether classical transient receptor potential (TRPC) channels integrate the intracellular signaling cascades evoked by the stimulated receptors and thereby contribute to the control of the membrane potential, Ca-influx and cell responses.
\end{abstract}

Methods-We created trpc4-, $\operatorname{trpc} 6$ - and trpc4/trpc6-gene deficient mice and analyzed them for intestinal smooth muscle function in vitro and in vivo.

Results-In intestinal smooth muscle cells TRPC4 forms a $55 \mathrm{pS}$ cation channel and underlies $>80 \%$ of the muscarinic receptor-induced cation current or $\mathrm{mI}_{\mathrm{CAT}}$. The residual $\mathrm{mI}_{\mathrm{CAT}}$ depends on the expression of TRPC6 indicating that TRPC6 and TRPC4 determine $\mathrm{mI}_{\mathrm{CAT}}$ channel activity independent of other channel subunits. In TRPC4-deficient ileal mocytes the carbachol-induced membrane depolarizations are greatly diminished and the atropine sensitive contraction elicited by

(C) 2009 The American Gastroenterological Association. Published by Elsevier Inc. All rights reserved.

Author for correspondence: Veit Flockerzi, Phone: (+49) 6841 1626400, Fax: (+49) 6841 1626402, E-mail: veit.flockerzi@uks.eu, Marc Freichel, (+49) 6841 1647879, (+49) 6841 1626402, marc.freichel@uks.eu.

VVT, AVZ, MF and VF contributed to all aspects of the manuscript, MXZ to acquisition of data from HEK 293 cells and critical revision of the manuscript, TA to protein chemistry, SEP to RT-PCR; AD and LB provided TRPV6-deficient mice.

Publisher's Disclaimer: This is a PDF file of an unedited manuscript that has been accepted for publication. As a service to our customers we are providing this early version of the manuscript. The manuscript will undergo copyediting, typesetting, and review of the resulting proof before it is published in its final citable form. Please note that during the production process errors may be discovered which could affect the content, and all legal disclaimers that apply to the journal pertain.

Conflicts of interest

No conflicts of interest exist 
acetylcholine release from excitatory motor neurons is greatly reduced. Additional deletion of TRPC6 aggravates these effects. Intestinal transit is slowed down in mice lacking TRPC4 and TRPC6.

Conclusions-In intestinal smooth muscle cells TRPC4 and TRPC6 channels are gated by muscarinic receptors and are responsible for $\mathrm{mI}_{\mathrm{CAT}}$. They couple muscarinic receptors to depolarization of intestinal smooth muscle cells, voltage-activated $\mathrm{Ca}^{2+}$-influx and contraction and thereby accelerate small intestinal motility in vivo.

\section{INTRODUCTION}

Many visceral smooth muscles, including those of the gastrointestinal tract, typically coexpress M2 and M3 muscarinic receptor subtypes which mediate the physiological action of the parasympathetic neurotransmitter acetylcholine in evoking smooth muscle excitation and contraction (1-3). Stimulation of muscarinic receptors causes the opening of non-selective cationic channels in smooth muscle cells of the gastrointestinal tract (1-9). Thereby depolarization is produced and it is assumed that these electrical events in turn result in increased $\mathrm{Ca}^{2+}$ influx via voltage-dependent $\mathrm{Ca}^{2+}$ channels, smooth muscle contraction and promotion of intestinal motility. Accordingly, it has been hypothesized that the generation of these muscarinic receptor-induced non-selective cation currents $\left(\mathrm{mI}_{\mathrm{CAT}}\right)$ is the mechanism coupling acetylcholine actions to membrane depolarization, voltage-dependent $\mathrm{Ca}^{2+}$ influx and cell responses. However, decisive evidence on this mechanism is still lacking.

TRPC channels are downstream effectors of G protein-coupled receptors $(10 ; 11)$ including muscarinic receptors and in smooth muscle cells these channels are widely assumed to underlie non-selective cation currents $(12 ; 13)$. However, their precise role in physiological processes is often uncertain because channels bearing biophysical and regulatory features similar to the overexpressed TRPC channels have not been unequivocally identified in native cells. The lack of appropriate channel blockers and agonists as well as suitable antibodies to identify TRPC proteins in primary cells has only escalated this problem. In this study we used isolated cells and tissues prepared from several lines of TRPC knockout mice to define the proteins which form the molecular basis of channel activity responsible for $\mathrm{mI}_{\mathrm{CAT}}$ and to analyze their impact on intestine smooth muscle contraction in vitro and in vivo. Our data demonstrate that channel activity depends on TRPC4 and TRPC6, which contribute essentially to neurogenic cholinergic contraction of ileal smooth muscle strips and gastrointestinal smooth muscle activity in vivo.

\section{MATERIALS and METHODS}

\section{Animal models}

All animal experiments were done in accordance to the Universität des Saarlandes Ethic Regulations and the animal welfare committees of the Saarland. Wild-type mice (129SvJ or F1 generation of $129 \mathrm{SvJ}$ and C57B16/J), TRPC4-/- mice (14), TRPC6-/- mice (15) and compound TRPC4/TRPC6 double knockout mice obtained by intercrossing of TRPC4-/- with TRPC6-/- mice were used in this study. Methods used for genotyping (Fig. S1) and smooth muscle isolation from these mice are described in the Supporting Document.

\section{Electrophysiology}

Standard whole-cell patch-clamp recordings were performed using borosilicate patch pipettes (2-3 M $\Omega$ ) (16) and an EPC-9 patch-clamp amplifier (HEKA Elektronic). For single-channel recordings patch pipettes (5-10 M $\Omega$ ) were coated with Sylgard (World Precision Instruments). 


\section{Contraction recordings}

Longitudinal layer muscle strips $(5-7 \mathrm{~mm})$ were tied at both ends by silk suture, suspended from a force-displacement transducer (ADInstruments), and placed in an isolated tissue bath.

\section{Small intestine transit}

Small intestine transit was essentially performed as in $(17 ; 18)$.

Full description of cell isolation technique, solutions and protocols used for electrophysiological experiments, contraction recordings and intestinal transit is given in the Supporting Document Methods.

\section{Statistical analysis}

The data were analysed and plotted using MicroCal Origin software (Micro-Cal Software, Inc., Northampton, MA, USA); for statistical tests GraphPad Prism (GraphPad Software, Inc. San Diego, CA, USA) was used. Values are given as the means \pm s.e.m; $n$ represents the number of cells tested. Unless otherwise noted, for comparison of two groups we used two-tailed unpaired Student's $t$ tests and for more than two groups one-way ANOVAs followed by the Dunnett's Multiple Comparison.

\section{RESULTS}

\section{Muscarinic cation currents $\left(\mathrm{ml}_{\mathrm{CAT}}\right)$ in murine ileal smooth muscle cells}

External application of carbachol $(100 \mu \mathrm{M})$ to isolated single smooth muscle myocytes caused an inward current (Fig. 1A) with the typical features of $\mathrm{mI}_{\mathrm{CAT}}$ characterized in guinea pig myocytes: Its current-voltage (I-V) relationship was U-shaped at negative potentials and $\mathrm{E}_{\mathrm{rev}}$ was close to $0 \mathrm{mV}$ (Fig. 1 and Fig S2). The mean density of this current amounts to -11.8 $\pm 0.4 \mathrm{pA} / \mathrm{pF}$ at $-50 \mathrm{mV}$ and $11.0 \pm 1.0 \mathrm{pA} / \mathrm{pF}$ at $+50 \mathrm{mV}$ ( $\mathrm{n}=53$ cells obtained from 14 mice) (Fig. 1D left).

In guinea pig myocytes $\mathrm{mI}_{\mathrm{CAT}}$ depends on synergistic activation by Gi/o-coupled and Gqcoupled muscarinic receptors (19-26). Likewise, in murine ileal cells $\mathrm{mI}_{\mathrm{CAT}}$ is inhibited both following pertussis toxin (PTX) pretreatment (Fig. S2B) and by increasing concentrations of the phospholipase C (PLC) inhibitor U73122 (Fig. S2C,D). Phospholipase C inhibition reduces formation of inositol 1,4,5-trisphosphate $\left(\mathrm{IP}_{3}\right)$ and diacylglycerol (DAG) while preventing the breakdown of phosphatidylinositol 4,5-bisphosphate $\left(\mathrm{PIP}_{2}\right)$. Similar to previous studies (25;

26) we found that $\mathrm{IP}_{3}$ and DAG seem not to play an important role in $\mathrm{mI}_{\mathrm{CAT}}$ regulation (Fig. S3) but like in guinea pig ileal myocytes (24) agonist-activated $\mathrm{mI}_{\mathrm{CAT}}$ is strongly inhibited by intracellularly applied PIP $_{2}$ (Fig. S2E).

\section{TRPC $4 \alpha / T R P C 4 \beta$ constitute channels which account for the greater part of $\mathrm{ml}_{\mathrm{CAT}}$}

These initial results indicate that the carbachol-induced currents of murine ileal myocytes share the biophysical and regulatory properties with the $\mathrm{mI}_{\mathrm{CAT}}$ of guinea pig myocytes. They also resemble expressed TRPC4 urrents $(24 ; 27 ; 28)$. The two TRPC4 isoforms TRPC $4 \alpha(\sim 100 \mathrm{kDa})$ and TRPC $4 \beta(\sim 93 \mathrm{kDa})$ are readily detectable in microsomal membranes from ileal myocytes isolated from wild-type mice but not in those from TRPC4-/- mice (Fig. 1E).

Compared to the wild-type myocytes, the carbachol-evoked current was considerably reduced in TRPC4-deficient cells (Fig. 1A). The resulting I-V obtained from TRPC4 deficient cells is almost linear (Fig. 1A) and the current densities at $-50 \mathrm{mV}(-1.9 \pm 0.3 \mathrm{pA} / \mathrm{pF})$ and $+50 \mathrm{mV}$ $(1.6 \pm 0.4 \mathrm{pA} / \mathrm{pF} ; \mathrm{n}=10$ cells $)$ amount to $16.1 \%(-50 \mathrm{mV})$ and $15.3 \%(+50 \mathrm{mV})$ of the current densities in wild-type cells (Fig. 1D). Similar results were obtained when $\mathrm{mI}_{\mathrm{CAT}}$ was activated 
by intracellular infusion of GTP $\gamma \mathrm{S}\left(200 \mu \mathrm{M}\right.$, Fig. $1 \mathrm{D}$ right) or $\mathrm{AlF}_{4}^{-}$(data not shown), both directly activate G-proteins (29). After formation of the whole-cell configuration an inward current gradually developed in the presence of GTP $\gamma \mathrm{S}$ which was indistinguishable from carbachol-induced $\mathrm{mI}_{\mathrm{CAT}}$ in terms of the shape of the $\mathrm{I}-\mathrm{V}$ curve and maximal current amplitude, which reached a maximum level within 3 to $10 \mathrm{~min}$ after breakthrough. Current densities at $-50 \mathrm{mV}$ and $+50 \mathrm{mV}$ were $-14.7 \pm 1.0 \mathrm{pA} / \mathrm{pF}$ and $13.7 \pm 1.0 \mathrm{pA} / \mathrm{pF}$ (Fig. 1D right) in wild-type cells $(\mathrm{n}=24$, from 4 animals) and $-2.3 \pm 0.2 \mathrm{pA} / \mathrm{pF}$ and $2.1 \pm 0.4 \mathrm{pA} / \mathrm{pF}$ in TRPC4deficient cells ( $\mathrm{n}=35$, from 5 animals), respectively. Whereas $\mathrm{mI}_{\mathrm{CAT}}$ can be potentiated by a rise in $\mathrm{Ca}^{2+}(30)$, the remaining current in TRPC4-deficient myocytes, $\mathrm{I}_{\mathrm{C} 4-/-}$, is no longer affected when $\mathbf{C a}^{2+}$ in the pipette solution is increased to $0.5 \mu \mathbf{M}$ (not shown). The whole cell capacitances of wild-type cells $(28.0+0.9 \mathrm{pF}, \mathrm{n}=122)$ and TRPC4-deficient cells $(29.2+0.9$ $\mathrm{pF}, \mathrm{n}=133$ ) are not different $(\mathrm{p}=0.38)$. In addition, carbachol-induced $\mathrm{Ca}^{2+}$-release from intracellular stores is not affected by the lack of TRPC4 (wild-type, $\mathrm{n}=10$ cells, TRPC ${ }^{-/-}$, $\mathrm{n}=14$; Fig. S4) indicating that possible changes of PLC activity and $\mathrm{IP}_{3}$ formation could not account for the greatly reduced in $\mathrm{mI}_{\mathrm{CAT}}$.

Single channel studies of outside-out patches excised in the presence of carbachol revealed activity of three types of cationic channels with unitary conductances of $7.2 \pm 0.4 \mathrm{pS}(\mathrm{n}=43)$, $55 \pm 8 \mathrm{pS}(\mathrm{n}=14)$, and $116 \pm 14 \mathrm{pS}(\mathrm{n}=26)$ in ileal myocytes from wild-type mice (Fig. 2). Unitary currents through these channels reversed close to the $\mathrm{Cs}^{+}$equilibrium potential at 0 $\mathrm{mV}$. These values roughly correspond to the 10,57 and $130 \mathrm{pS}$ conductances in guinea pig myocytes (31) and the 20,70 and 140 conductances in murine myocytes (23;32). The activity of the $116 \mathrm{pS}$ channel (Fig. 2 C) was detected in 18 out of 47 patches and consisted of bursts of very brief openings. The longest open times were about some milliseconds and this channel displayed only a very low open probability $\left(\mathrm{P}_{\mathrm{O}}<0.1\right.$; Fig. $\left.2 \mathrm{C}\right)$.

In contrast, the $\mathrm{P}_{\mathrm{O}}$ of the $7 \mathrm{pS}$ and $55 \mathrm{pS}$ conductance channels (Fig 2A,B) were strongly potential dependent. At positive potentials their $\mathrm{P}_{\mathrm{O}}$ strongly increased with membrane depolarization, whereas at potentials below $-60 \mathrm{mV}$ the $\mathrm{P}_{\mathrm{O}}$ remarkably decreased very similarly to the carbachol-induced whole cell current. However, the $\mathrm{P}_{\mathrm{O}}$ of the $7 \mathrm{pS}$ conductance channel was also low $\left(\mathrm{P}_{\mathrm{O}}<0.1\right)$; and together with its relatively small unitary current amplitude, this channel would make only a small contribution to the whole cell current (Fig 2A).

The intermediate $55 \mathrm{pS}$ conductance channel (Fig. 2B) was present in 14 out of 47 patches taken from wild-type myocytes but a similar activity was not detectable in 27 patches from TRPC4-deficient myocytes indicating that the $55 \mathrm{pS}$ channels are formed by TRPC4. In contrast the small and large conductance channels were detectable in cells of both genotypes at a similar frequency (7pS: wild-type, 27 in 47 (57\%); $\mathrm{TRPC}^{-1-}, 17$ in 27 (63\%); $116 \mathrm{pS}$ : wild-type, 18 in 47 (38\%); TRPC4 ${ }^{-/-}, 8$ in $27(30 \%)$ ). Taken together these data allow for the firm conclusion that TRPC4 underlies the intermediate conductance channels, which in turn account for the major part (>80\%) of the steady state whole-cell I-V relationship, characteristically U-shaped at negative potentials (31).

\section{TRPC6 channels contribute to mlCAT}

Another TRPC channel could account for the remaining $\mathrm{mI}_{\mathrm{CAT}}$ in TRPC4-deficient myocytes ( $\left.\mathrm{mI}_{\mathrm{C} 4-/-}\right)$ (Fig. 1A). In addition to TRPC4, TRPC6 and TRPC7 were consistently detectable by RT-PCR in intestinal smooth muscles ((33) and Fig. S5). By western blotting the TRPC6 protein was detectable in ileal myocytes (Fig. $1 \mathrm{~F}$ ) as a $\sim 95 \mathrm{kDa}$ protein and higher molecular weight bands which might represent glycosylated versions (34) of TRPC6 because they are also absent in the same type of cells from TRPC6 knock-out mice (Fig. 1F). Bath application of TRPC6 activator (35), the membrane-permeable analogue of DAG, 1-oleoyl-2-acetyl-snglycerol (OAG, $50 \mu \mathrm{M}$ ) activates a current (Fig. S6) indistinguishable from the carbachol- 
induced $\mathrm{mI}_{\mathrm{C} 4---}$ being almost linear at negative potentials and slightly outwardly rectifying at positive potentials $(-50 \mathrm{mV}:-1.5 \pm 0.2 \mathrm{pA} / \mathrm{pF},+50 \mathrm{mV}: 1.6 \pm 0.2 \mathrm{pA} / \mathrm{pF}, \mathrm{n}=13)$.

In TRPC6 ${ }^{-1-}$ myocytes the characteristic U-shaped I-V relationship of mI $\mathrm{CAT}_{\mathrm{CA}}$ was still preserved (Fig. $1 \mathrm{~B}$, right panel) but currents were slightly but significantly $(\mathrm{p}=0.002)$ smaller than in wild-type myocytes $(-50 \mathrm{mV},-9.6 \pm 0.5 \mathrm{pA} / \mathrm{pF} ;+50 \mathrm{mV}, 7.8 \pm 0.7 \mathrm{pA} / \mathrm{pF}, \mathrm{n}=28$ cells from 7 animals) (Fig. $1 \mathrm{~B}, \mathrm{D})$. The $7 \mathrm{pS}$ and $116 \mathrm{pS}$ conductance channels were still detectable in the myocytes from TRPC6-deficient mice (7 pS, 14 in 27 patches; $116 \mathrm{pS}, 11$ in 27 patches) as was the $55 \mathrm{pS}$ channel (10 in 27 patches) indicating that TRPC4 and TRPC6 underlie different channels, with TRPC4 channels being responsible for the remaining current in TRPC6-deficient cells, $\mathrm{mI}_{\mathrm{C} 6-/-}$, whereas TRPC6-channels might underlie $\mathrm{mI}_{\mathrm{C} 4-/- \text {. To test this }}$ assumption we generated a mouse line deficient in both TRPC4 and TRPC6. These mice are viable and fertile allowing us to isolate ileal smooth muscle cells to record mI $\mathrm{CAT}_{\mathrm{CAT}}$. As shown in Fig. $1 \mathrm{C}$ and $\mathrm{D}$ carbachol-induced currents were hardly detectable in these myocytes $(-50$ $\mathrm{mV},-0.30 \pm 0.04 \mathrm{pA} / \mathrm{pF} ; 50 \mathrm{mV}, 0.26 \pm 0.06 \mathrm{pA} / \mathrm{pF} ; \mathrm{n}=24$ cells from 6 animals). From these results we conclude that TRPC4 and TRPC6 proteins are the only essential components of channels responsible for $\mathrm{mI}_{\mathrm{CAT}}$ in ileal smooth muscle cells.

\section{The muscarinic cation current $\mathrm{ml}_{\mathrm{CAT}} / \mathrm{ml}_{\mathrm{TRPC}}$ couples muscarinic receptor stimulation to membrane depolarization in ileal smooth muscle cells}

To assess the physiological function of $\mathrm{mI}_{\mathrm{CAT}}$ we recorded membrane potentials in current clamp mode in wild-type, TRPC4-deficient and TRPC4-/TRPC6-deficient myocytes following application of carbachol (Fig. 3). Apart from rarely occurring spontaneous hyperpolarizations (less than $10 \%$ of cells) myocytes exhibited no electrical activity. The mean resting membrane potentials were not significantly different in cells from the three genotypes (wild-type cells, $-58 \pm 1 \mathrm{mV}, \mathrm{n}=33$; TRPC4- $--,-55 \pm 1 \mathrm{mV}, \mathrm{n}=35$; $\left.\mathrm{TRPC}^{-/-} / \mathrm{TRPC}^{-/-},-59 \pm 1, \mathrm{n}=15\right)(\mathrm{p}=0.2)$ (Fig. 3A-D). Application of carbachol to wild-type cells led to depolarization in a concentration-dependent manner (Fig. 3A). Carbachol at $1 \mu \mathrm{M}$ led to a transient depolarization (Fig. 3A) accompanied and followed by rare periodical and short spike depolarizations, which lasted less than $1 \mathrm{~s}$. Increasing the carbachol concentration induced more pronounced and longer lasting depolarizations (Fig. 3A). In TRPC-deficient myocytes (Fig. 3B,C), however, almost no depolarization was detectable at $1 \mu \mathrm{M}$, and at 10 to $100 \mu \mathrm{M}$, concentrations which are effective in inducing $\mathrm{mI}_{\mathrm{CAT}}$, depolarization is clearly reduced compared to wild-type cells. Action potentials were rarely observed and only at the beginning of the depolarization. As an estimate of the effect, membrane potential during maximal carbachol-induced depolarization lasting longer than $1 \mathrm{~s}$ was determined and values averaged and plotted in Fig. 3D.

Depolarization induced by carbachol is significantly decreased in the TRPC4-deficient cells $(10 \mu \mathrm{M},-38 \pm 1 \mathrm{mV}, \mathrm{n}=16 ; 100 \mu \mathrm{M},-32 \pm 1 \mathrm{mV}, \mathrm{n}=20)$ compared to wild-type cells $(10 \mu \mathrm{M}$, $-10 \pm 1 \mathrm{mV}, \mathrm{n}=18 ; \mathrm{p}<0.001 ; 100 \mu \mathrm{M},-4 \pm 1 \mathrm{mV}, \mathrm{n}=20, \mathrm{p}<0.001)$ with the reduction even more noticeable in the double-knock-out cells $(10 \mu \mathrm{M},-50 \pm 2 \mathrm{mV}, \mathrm{n}=8, \mathrm{p}<0.001 ; 100 \mu \mathrm{M}$, $-45 \pm 2 \mathrm{mV}, \mathrm{n}=7, \mathrm{p}<0.001)$. These results prove that a major function of TRPC4 and TRPC6 channels underlying $\mathrm{mI}_{\mathrm{CAT}}$ is to link muscarinic receptor stimulation with membrane depolarization. Also notable, the slow oscillations which normally trigger spike potential discharge and occur through potentiation of $\mathrm{mI}_{\mathrm{CAT}}$ by $\mathrm{Ca}^{2+}$ release $(8 ; 22)$, are lacking in TRPC4-deficient myocytes (Fig. 3B,C). This is expected since $\mathrm{I}_{\mathrm{C} 4-/-}$ is no longer sensitive to intracellular $\mathrm{Ca}^{2+}$.

\section{L-type Ca channel activity is not affected in TRPC-deficient ileal smooth muscle cells}

In most smooth muscle tissues including the intestine $\mathrm{L}$-type $\mathrm{Ca}^{2+}$ channel currents are essential for contraction (36;37). We therefore recorded L-type $\mathrm{Ca}^{2+}$ channel currents and monitored expression of the channel proteins in isolated ileal myocytes. Maximal current densities obtained by depolarization to $+10 \mathrm{mV}$ were not different $(\mathrm{p}=0,3)$ in wild-type cells $(-12.5 \pm$ 
$0.9 \mathrm{pA} / \mathrm{pF} ; \mathrm{n}=33$ cells from 5 animals $)$ compared to TRPC4 deficient cells $(-11.4 \pm 0.6 \mathrm{pA} /$ $\mathrm{pF}, \mathrm{n}=56$ cells, 5 animals) (Fig. S7A) and potentials for half-maximal activation were not altered (Fig. S7B). Additionally, expression levels of $\mathrm{Ca}^{2+}$ channel proteins $\mathrm{CaV} 1.2(\alpha 1 \mathrm{C})$, $\mathrm{CaV} \beta 2$ and $\mathrm{CaV} \beta 3$ were not affected by the lack of TRPC4 (Fig. S7C).

\section{Smooth muscle contraction, small intestinal transit and $\mathrm{ml}$ CAT/mIC4C6}

To investigate the role of $\mathrm{mI}_{\mathrm{CAT}} / \mathrm{mI}_{\mathrm{C} 4 \mathrm{C} 6}$ for intestinal contractility we applied a transmural electrical field stimulation (EFS) protocol to isolated strips from the ileal longitudinal smooth muscle layer. The protocol consisted of repetitive short voltage pulses of $1 \mathrm{~ms}$ at increasing frequencies (Fig. S8A). Contraction increased with the frequency of the pulses and was maximal at a frequency of $30 \mathrm{~Hz}$ (Fig. S8A). These short pulses at $30 \mathrm{~Hz}$ are sufficient to stimulate excitatory cholinergic motor neurons present in the longitudinal muscle strips and promote acetylcholine release but at the same time should not directly affect smooth muscle cells which, apparently, lack fast low-threshold-depolarizing conductances, which could be activated by the short pulses.

Longitudinal muscle strips from ileum of TRPC $4^{-1-}$ mice and TRPC4-/TRPC6-deficient mice (TRPC4 ${ }^{-/-} / \mathrm{C}^{-/-}$) exhibited slow spontaneous activity with contraction amplitudes and frequencies similar to those from wild-type mice (Fig. 4A-C, lower panel) which were blocked by nifedipine $(10 \mu \mathrm{M})$ (Fig. $4 \mathrm{D}$ lower) but not by atropine ( $1 \mu \mathrm{M})$ (Fig. 4D upper). EFS at 30 $\mathrm{Hz}$ applied for $10 \mathrm{~s}$ induced a rapid and potent increase in the spontaneous contractions in muscle strips from wild-type animals (Fig. 4A, lower panel). The contraction rapidly reached a maximum and gradually decreased during the stimulation. The contraction of each strip was normalised (Fig. 4E) to the peak of the phasic contraction induced by application of $80 \mathrm{mM}$ potassium to the bath solution (Fig. 4A-C upper panel). Raising extracellular potassium depolarises the cells independent of receptor-induced signalling cascades and activates voltage-dependent $\mathrm{Ca}^{2+}$-entry which was not changed in the knock-out cells (Fig. S7)

EFS induced contractions could not be elicited in the presence of tetrodotoxin $(1 \mu \mathrm{M})$ (data not shown) and were blocked in the presence of atropine (atr, $1 \mu \mathrm{M})$ by $\sim 93 \%(\mathrm{n}=7)$ or nifedipine (nif, $10 \mu \mathrm{M})$ by $\sim 95 \%(\mathrm{n}=12)(\mathrm{Fig}$. 4D). The block in the presence of atropine and nifedipine indicates that the increased contraction involves muscarinic receptors and voltage activated dihydropyridine-sensitive L-type $\mathrm{Ca}^{2+}$ channels most probably located in the plasma membrane of the smooth muscle cells whereas tetrodotoxin acts on sodium channels. Compared to wild-type $(\mathrm{n}=16)$ the amplitude of EFS induced contraction was reduced in $\mathrm{TRPC}^{-1-}$ strips by $\sim 64 \%$ (Fig $4 \mathrm{~B}, \mathrm{E}$ ) and in $\mathrm{TRPC}^{-/-} / \mathrm{C}^{-/-}$strips by $\sim 72 \%$ (Fig. 4C,E).

A similar reduction was observed, when EFS induced contraction of muscle strips from TRPC4- and TRPC4/TRPC6-deficient mice were monitored in the presence of inhibitors of neurotransmission (Fig S8B and methods in Supporting Document) which might have been co-released together with acetylcholine during EFS or which are formed as a consequence of acetylcholine release, supporting the conclusion that EFS-induced contraction reduced in the TRPC4-and TRPC4/TRPC6-deficient mice is mediated by acetylcholine.

To determine whether this impairment of acetylcholine induced contraction translates into changes of small intestine motility in vivo, $0.25 \mathrm{~mL}$ of charcoal $(10 \%(\mathrm{w} / \mathrm{v}))$ were applied to mice by orogastric gavage. After $60 \mathrm{~min}$ mice were sacrificed for exposure and examination of the gastrointestinal tract and transit of charcoal was determined as the measured distance from the pyloric sphincter to the leading edge of the charcoal stained area within the intestine (Fig. 4F) and amounted to $41.3 \pm 1.2 \mathrm{~cm}$ (wild-type mice; $\mathrm{n}=8$ ) and $31.6 \pm 1.1 \mathrm{~cm}$ (TRPC4 ${ }^{-l-} / \mathrm{C6}^{-1-}$-mice; $\left.\mathrm{n}=10\right)(\mathrm{p}<0.000025)$. A similar and significant reduction was also observed after normalizing these values to tibia length (wild-type, $2.25 \pm 0.07$; $\mathrm{TRPC}^{-1-}$ / 
$\left.\mathrm{C} 6^{-1-}, 1.83 \pm 0.06\right)(\mathrm{p}>0,00046)$ demonstrating that TRPC4/TRPC6 channels are important in promoting intestinal motility in vivo.

\section{DISCUSSION}

In a first series of experiments we show that $\mathrm{mI}_{\mathrm{CAT}}$ in mouse ileal myocytes shares the regulatory and biophysical properties of the current in guinea pig cells. We then demonstrate that TRPC $4 \alpha$, TRPC4 $\beta$, and TRPC6 proteins are expressed in ileal myocytes and that $\mathrm{mI}_{\mathrm{CAT}}$ is not longer detectable in TRPC4/TRPC6-deficient myocytes. Resting membrane potential and spontaneous contractile activity of longitudinal smooth muscle fibres are not affected by the lack of TRPC4 and TRPC6 whereas muscarinic receptor induced depolarizations and contractile responses are significantly reduced and, as a consequence, small intestinal transit of charcoal is slowed down in vivo.

Members of the TRPC subfamily have been implicated to constitute cationic channels in smooth muscle and by analyzing genetically modified mice it was recently shown that TRPC6 channels underlie hypoxia-induced cation influx in pulmonary smooth muscle cells (38) and are involved in the regulation of vascular smooth muscle tone (15), whereas pressure-induced and store-operated cation influx in vascular smooth muscle (39) like store-operated cation influx in platelets (40) is independent of TRPC1. Genetic inactivation of another TRPC gene, TRPC4, resulted in impaired endothelium dependent vasorelaxation and loss of a $\mathrm{Ca}^{2+}$ selective store-operated current (14), changes in microvascular permeability (41) and GABA release from thalamic interneurons (42). TRPC4 channels have also been implicated in carbachol-induced cationic currents in stomach smooth muscle cells but whether the TRPC4 protein is expressed in these cells and its impact on smooth muscle contraction has not been shown (43).

We demonstrate here that two TRPC4 proteins of $\sim 100 \mathrm{kDa}$ (TRPC $4 \alpha$ ) and $\sim 93 \mathrm{kDa}$ (TRPC4 $\beta$ ) are expressed in murine ileal myocytes but are absent in the same cell type from TRPC4 knock-out mice; they are also co-expressed in brain (44) and in macrovascular endothelium (14). When the longer TRPC $4 \alpha$ is precipitated, the TRPC $4 \beta$ is retained (Fig. 5A,B) although it is not recognized by the precipitating antibody (Fig. 5A). This result is in line with the coassembly of TRPC $4 \alpha$ and TRPC $4 \beta$ to TRPC $4 \alpha /$ TRPC $4 \beta$ channels, whereas there is no evidence of direct interaction of TRPC4 and TRPC6, even after over-expressing their cDNAs in COS7 cells (Fig. 5C).

In ileal myocytes stimulation of $\mathrm{M}_{2}$ and $\mathrm{M}_{3}$ muscarinic receptors provide concurrent, but different, signals for $\mathrm{mI}_{\mathrm{CAT}}$ channel opening $(19 ; 45 ; 46)$, which appear to require PTXsensitive Gi/o- proteins, PLC enzymatic activity, and a rise in $\left[\mathrm{Ca}^{2+}\right]_{\mathrm{i}}$, which increases channel's open probability (for discussion of the $\mathrm{Ca}^{2+}$-dependence of $\mathrm{mI}_{\mathrm{CAT}}$ and ion selectivity of channels underlying $\mathrm{mI}_{\mathrm{CAT}}$ see Supporting Document). Deletion of the TRPC4 gene in mice reduced $\mathrm{mI}_{\mathrm{CAT}}$ by $84 \%$. In addition the $55 \mathrm{pS}$ channel recorded upon carbachol stimulation in wild-type cells was no longer detectable in the TRPC4-knockout cells indicating that TRPC4 proteins are essential components of the responsible channel. This $55 \mathrm{pS}$ conductance channel resembles the $42 \mathrm{pS}$ and $57 \mathrm{pS}$ conductance channels recorded from TRPC4 expressing HEK 293 cells (47) and guinea pig ileal myocytes (31); their mean patch I-V relationships closely resemble the muscarinic whole cell current in ileal myocytes showing the reduced $\mathrm{P}_{\mathrm{O}}$ at potentials below $-60 \mathrm{mV}$ and a reversal potential close to $0 \mathrm{mV}$ (Fig. 2B) (For a discussion of single channel conductance of TRPC4 in HEK 293 cells and in ileum smooth muscle cells see Supporting Document).

TRPC4 channel activity in HEK cells depends on intracellular $\mathrm{Ca}^{2+}(24 ; 27)$ and it is this aspect of TRPC4 modulation which may explain concurrent oscillations of $\left[\mathrm{Ca}^{2+}\right]_{\mathrm{i}}, \mathrm{mI}_{\mathrm{CAT}}$ and 
membrane potential observed in wild-type cells but not in TRPC4-deficient myocytes (Fig. 3). Membrane potential oscillations, often proceeded by spike potentials, normally occur through potentiation by $\mathrm{mI}_{\mathrm{CAT}}$ by $\mathrm{Ca}^{2+}$ release events $(48 ; 49)$, but are absent in TRPC4-deficient myocytes because $\mathrm{I}_{\mathrm{C} 4-/-}$ is no longer sensitive to intracellular $\mathrm{Ca}^{2+}$.

The contribution of TRPC6 to $\mathrm{mI}_{\mathrm{CAT}}$ is significant but considerably smaller than that of TRPC4. In myocytes deficient in both genes no $\mathrm{mI}_{\mathrm{CAT}}$ could be evoked by carbachol indicating that the remaining currents in TRPC6 deficient myocytes ( $\left.\mathrm{I}_{\mathrm{C} 6-/-}\right)$ are TRPC4 currents and that the remaining currents in TRPC4 deficient myocytes $\left(\mathrm{I}_{\mathrm{C} 4-/-}\right)$ are TRPC6 currents. $\mathrm{I}_{\text {TRPC6 } 6}$, can be activated in the presence of $\mathrm{OAG}$, resembling the remaining OAG-induced cationic current observed in PTX-treated mouse ileal cells (50).

In summary, TRPC4 and TRPC6 proteins are essential for muscarinic receptor-induced channel activities in this type of smooth muscle independent of the other channel proteins. By integrating downstream effects of muscarinic receptor stimulation they are pivotal in coupling muscarinic receptors to membrane potential, $\mathrm{Ca}^{2+}$ influx and cell responses (Fig. 6). The decisive role of TRPC4/TRPC6 shown here to occur in smooth muscle could also be relevant in other cell types including neurons, where TRPC channels should also respond to metabotropic receptors and cause membrane depolarization.

\section{Supplementary Material}

Refer to Web version on PubMed Central for supplementary material.

\section{Acknowledgments}

We thank Christine Wesely, Kerstin Fischer, Stefanie Buchholz, Katrin Schumacher for their precious assistance, Marcel Meissner, Adolfo Cavalié for helpful discussions, Sabine Pelvay, Ramona Gölzer, Martin Jung for immunizing and bleeding rabbits.

Grant Support: Supported by the Intramural Research Programs of the NIH, National Institute of Environmental Health Sciences (LB), by NIH grant DK081654 (MXZ, AVZ), by HOMFOR (MF, VVT, SEP, VF), Deutsche Forschungsgemeinschaft and Forschungskommission der UdS (MF, VF), Fonds der Chemischen Industrie (VF).

\section{Reference List}

1. Kuriyama H, Kitamura K, Itoh T, et al. Physiological features of visceral smooth muscle cells, with special reference to receptors and ion channels. Physiol Rev 1998;78:811-920. [PubMed: 9674696]

2. Bolton TB, Prestwich SA, Zholos AV, et al. Excitation-contraction coupling in gastrointestinal and other smooth muscles. Annu Rev Physiol 1999;61:85-115. [PubMed: 10099683]

3. Sanders KM. Invited review: mechanisms of calcium handling in smooth muscles. J Appl Physiol 2001;91:1438-1449. [PubMed: 11509546]

4. Bolton TB. The depolarizing action of acetylcholine or carbachol in intestinal smooth muscle. J Physiol 1972;220:647-671. [PubMed: 5016040]

5. Klevets, MY.; Shuba, MF. Mechanisms of adrenaline, noradrenaline and acetylcholine effects on the electrophysiological properties of smooth muscle cells. Transactions of the 2nd Symposium on General Physiology: Synaptic Processes [in Russian]; Kiev, Naukova Dumka.. 1968. p. 92-107.

6. Inoue R, Isenberg G. Acetylcholine activates nonselective cation channels in guinea pig ileum through a G protein. Am J Physiol 1990;258:C1173-C1178. [PubMed: 1694399]

7. Wang YX, Fleischmann BK, Kotlikoff MI. M2 receptor activation of nonselective cation channels in smooth muscle cells: calcium and Gi/G(o) requirements. Am J Physiol 1997;273:C500-C508. [PubMed: 9277347]

8. Unno T, Kwon SC, Okamoto H, et al. Receptor signaling mechanisms underlying muscarinic agonistevoked contraction in guinea-pig ileal longitudinal smooth muscle. Br J Pharmacol 2003;139:337350. [PubMed: 12770939] 
9. So I, Kim KW. Nonselective cation channels activated by the stimulation of muscarinic receptors in mammalian gastric smooth muscle. J Smooth Muscle Res 2003;39:231-247. [PubMed: 15048016]

10. Ramsey IS, Delling M, Clapham DE. An introduction to TRP channels. Annu Rev Physiol 2006;68:619-647. [PubMed: 16460286]

11. Venkatachalam K, Montell C. TRP channels. Annu Rev Biochem 2007;76:387-417. [PubMed: 17579562]

12. Beech DJ, Muraki K, Flemming R. Non-selective cationic channels of smooth muscle and the mammalian homologues of Drosophila TRP. J Physiol 2004;559:685-706. [PubMed: 15272031]

13. Inoue R, Okada T, Onoue H, et al. The transient receptor potential protein homologue TRP6 is the essential component of vascular alpha(1)-adrenoceptor-activated $\mathrm{Ca}(2+)$-permeable cation channel. Circ Res 2001;88:325-332. [PubMed: 11179201]

14. Freichel M, Suh SH, Pfeifer A, et al. Lack of an endothelial store-operated Ca2+ current impairs agonist-dependent vasorelaxation in TRP4-/- mice. Nat Cell Biol 2001;3:121-127. [PubMed: 11175743]

15. Dietrich A, Mederos YS, Gollasch M, et al. Increased vascular smooth muscle contractility in TRPC6 -I- mice. Mol Cell Biol 2005;25:6980-6989. [PubMed: 16055711]

16. Hamill OP, Marty A, Neher E, et al. Improved patch-clamp techniques for high-resolution current recording from cells and cell-free membrane patches. Pflugers Arch 1981;391:85-100. [PubMed: 6270629]

17. Chang FY, Doong ML, Chen TS, et al. Vasoactive intestinal polypeptide appears to be one of the mediators in misoprostol-enhanced small intestinal transit in rats. J Gastroenterol Hepatol 2000;15:1120-1124. [PubMed: 11106090]

18. Torjman MC, Joseph JI, Munsick C, et al. Effects of isoflurane on gastrointestinal motility after brief exposure in rats. Int J Pharm 2005;294:65-71. [PubMed: 15814231]

19. Zholos AV, Bolton TB. Muscarinic receptor subtypes controlling the cationic current in guinea-pig ileal smooth muscle. Br J Pharmacol 1997;122:885-893. [PubMed: 9384504]

20. Rhee JC, Rhee PL, Park MK, et al. Muscarinic receptors controlling the carbachol-activated nonselective cationic current in guinea pig gastric smooth muscle cells. Jpn J Pharmacol 2000;82:331-337. [PubMed: 10875753]

21. Okamoto H, Prestwich SA, Asai S, et al. Muscarinic agonist potencies at three different effector systems linked to the $\mathrm{M}(2)$ or $\mathrm{M}(3)$ receptor in longitudinal smooth muscle of guinea-pig small intestine. Br J Pharmacol 2002;135:1765-1775. [PubMed: 11934818]

22. Unno T, Matsuyama H, Komori S. Interaction between the M2- and M3-receptor subtypes in muscarinic electrical and mechanical responses of intestinal smooth muscles. Neurophysiology 2003;35(34):290-301.

23. Sakamoto T, Unno T, Kitazawa T, et al. Three distinct muscarinic signalling pathways for cationic channel activation in mouse gut smooth muscle cells. J Physiol 2007;582:41-61. [PubMed: 17463038]

24. Otsuguro K, Tang J, Tang Y, et al. Isoform-specific inhibition of TRPC4 channel by phosphatidylinositol 4,5-bisphosphate. J Biol Chem 2008;283:10026-10036. [PubMed: 18230622]

25. Zholos AV, Tsytsyura YD, Gordienko DV, et al. Phospholipase C, but not InsP3 or DAG, -dependent activation of the muscarinic receptor-operated cation current in guinea-pig ileal smooth muscle cells. Br J Pharmacol 2004;141:23-36. [PubMed: 14662735]

26. Okamoto H, Unno T, Arima D, et al. Phospholipase C involvement in activation of the muscarinic receptor-operated cationic current in Guinea pig ileal smooth muscle cells. J Pharmacol Sci 2004;95:203-213. [PubMed: 15215645]

27. Plant TD, Schaefer M. TRPC4 and TRPC5: receptor-operated Ca2+-permeable nonselective cation channels. Cell Calcium 2003;33:441-450. [PubMed: 12765689]

28. Strubing C, Krapivinsky G, Krapivinsky L, et al. TRPC1 and TRPC5 form a novel cation channel in mammalian brain. Neuron 2001;29:645-655. [PubMed: 11301024]

29. Bigay J, Deterre P, Pfister C, et al. Fluoroaluminates activate transducin-GDP by mimicking the gamma-phosphate of GTP in its binding site. FEBS Lett 1985;191:181-185. [PubMed: 3863758]

30. Inoue R, Isenberg G. Intracellular calcium ions modulate acetylcholine-induced inward current in guinea-pig ileum. J Physiol 1990;424:73-92. [PubMed: 2118179] 
31. Zholos AV, Zholos AA, Bolton TB. G-protein-gated TRP-like cationic channel activated by muscarinic receptors: effect of potential on single-channel gating. J Gen Physiol 2004;123:581-598. [PubMed: 15111646]

32. Dresviannikov AV, Bolton TB, Zholos AV. Muscarinic receptor-activated cationic channels in murine ileal myocytes. Br J Pharmacol 2006;149:179-187. [PubMed: 16894345]

33. Walker RL, Hume JR, Horowitz B. Differential expression and alternative splicing of TRP channel genes in smooth muscles. Am J Physiol Cell Physiol 2001;280:C1184-C1192. [PubMed: 11287332]

34. Dietrich A, Schnitzler M, Emmel J, et al. N-linked protein glycosylation is a major determinant for basal TRPC3 and TRPC6 channel activity. J Biol Chem 2003;278:47842-47852. [PubMed: 12970363]

35. Hofmann T, Obukhov AG, Schaefer M, et al. Direct activation of human TRPC6 and TRPC3 channels by diacylglycerol. Nature 1999;397:259-263. [PubMed: 9930701]

36. Bolton TB. Mechanisms of action of transmitters and other substances on smooth muscle. Physiol Rev 1979;59:606-718. [PubMed: 37533]

37. Wegener JW, Schulla V, Koller A, et al. Control of intestinal motility by the Cav1.2 L-type calcium channel in mice. FASEB J. 2006

38. Weissmann N, Dietrich A, Fuchs B, et al. Classical transient receptor potential channel 6 (TRPC6) is essential for hypoxic pulmonary vasoconstriction and alveolar gas exchange. Proc Natl Acad Sci U S A 2006;103:19093-19098. [PubMed: 17142322]

39. Dietrich A, Kalwa H, Storch U, et al. Pressure-induced and store-operated cation influx in vascular smooth muscle cells is independent of TRPC1. Pflugers Arch. 2007

40. Varga-Szabo D, Authi KS, Braun A, et al. Store-operated Ca(2+) entry in platelets occurs independently of transient receptor potential (TRP) C1. Pflugers Arch. 2008

41. Tiruppathi C, Freichel M, Vogel SM, et al. Impairment of store-operated Ca2+ entry in TRPC4(-/-) mice interferes with increase in lung microvascular permeability. Circ Res 2002;91:70-76. [PubMed: 12114324]

42. Munsch T, Freichel M, Flockerzi V, et al. Contribution of transient receptor potential channels to the control of GABA release from dendrites. Proc Natl Acad Sci U S A 2003;100:16065-16070. [PubMed: 14668438]

43. Lee KP, Jun JY, Chang IY, et al. TRPC4 is an essential component of the nonselective cation channel activated by muscarinic stimulation in mouse visceral smooth muscle cells. Mol Cells 2005;20:435441. [PubMed: 16404161]

44. Flockerzi V, Jung C, Aberle T, et al. Specific detection and semi-quantitative analysis of TRPC4 protein expression by antibodies. Pflugers Arch 2005;451:81-86. [PubMed: 15965705]

45. Komori S, Kawai M, Takewaki T, et al. GTP-binding protein involvement in membrane currents evoked by carbachol and histamine in guinea-pig ileal muscle. J Physiol 1992;450:105-126. [PubMed: 1432705]

46. Yan HD, Okamoto H, Unno T, et al. Effects of G-protein-specific antibodies and G beta gamma subunits on the muscarinic receptor-operated cation current in guinea-pig ileal smooth muscle cells. Br J Pharmacol 2003;139:605-615. [PubMed: 12788820]

47. Schaefer M, Plant TD, Obukhov AG, et al. Receptor-mediated regulation of the nonselective cation channels TRPC4 and TRPC5. J Biol Chem 2000;275:17517-17526. [PubMed: 10837492]

48. Unno T, Inaba $\mathrm{T}$, Ohashi $\mathrm{H}$, et al. Role of $\mathrm{Ca} 2+$ mobilization in muscarinic receptor-mediated membrane depolarization in guinea pig ileal smooth muscle cells. Jpn J Pharmacol 2000;84:431437. [PubMed: 11202616]

49. Kohda M, Komori S, Unno T, et al. Carbachol-induced oscillations in membrane potential and $\left[\mathrm{Ca}^{2}\right.$ $\left.{ }^{+}\right]_{\mathrm{i}}$ in guinea-pig ileal smooth muscle cells. J Physiol 1998;511(Pt 2):559-571. [PubMed: 9706031]

50. Sakamoto T, Unno T, Matsuyama H, et al. Characterization of muscarinic receptor-mediated cationic currents in longitudinal smooth muscle cells of mouse small intestine. J Pharmacol Sci 2006;100:215226. [PubMed: 16538027] 
A

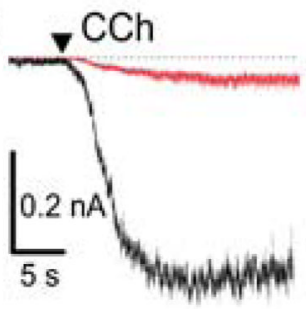

$\mathrm{B}$

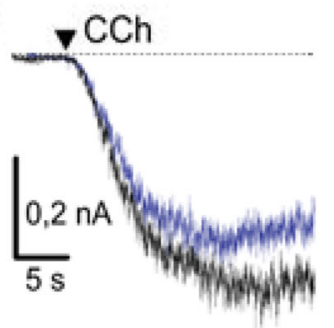

C

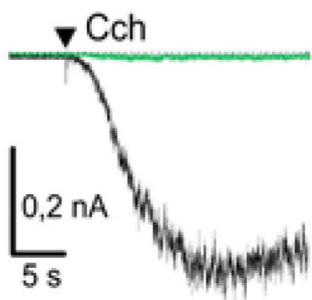

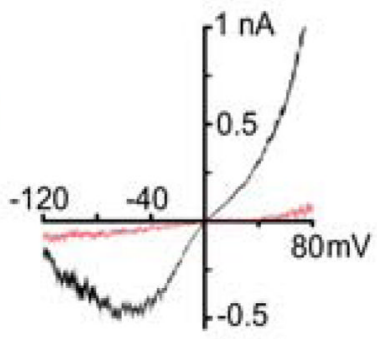
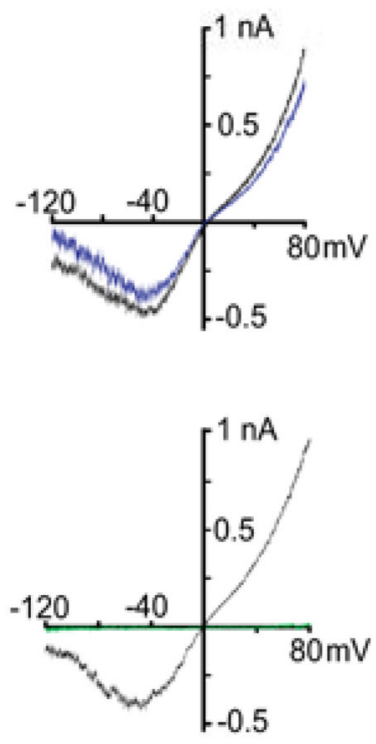

$\mathrm{D}$
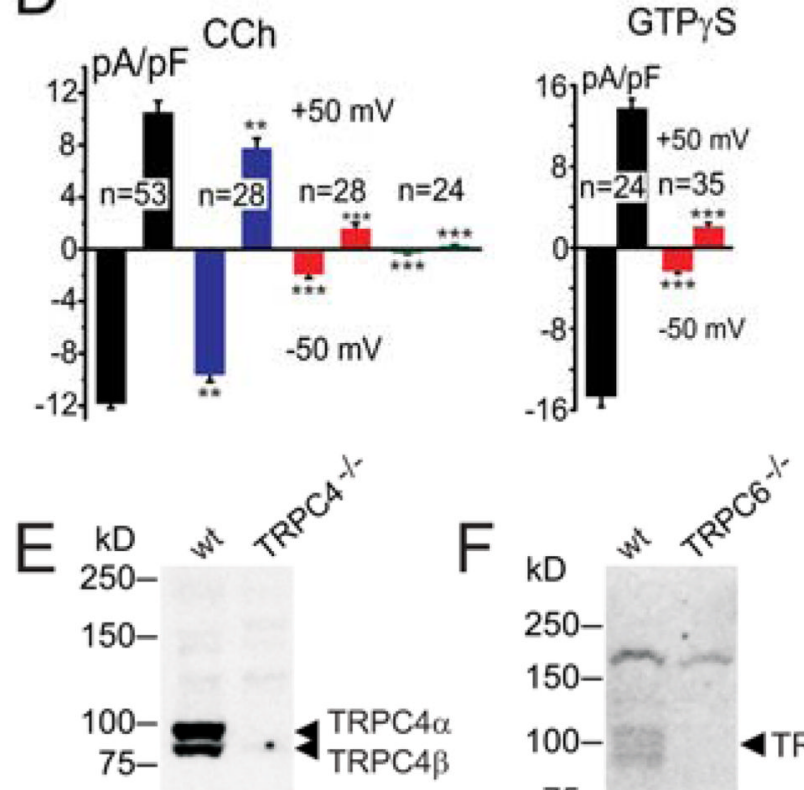

Figure 1. TRPC4 and TRPC6 underlie $\mathrm{mI}_{\mathrm{CAT}}$ in ileal smooth muscle cells

Muscarinic receptor-induced cation currents $\left(\mathrm{mI}_{\mathrm{CAT}}\right)$ in smooth muscle cells isolated from ileum of wild-type $\left(+/+\right.$, black), $\mathrm{TRPC}^{-/-}\left(\right.$red, A), TRPC $^{-/-}$(blue, B) and TRPC $4^{-1-}$ / $\mathrm{TRPC}^{-1-}$ mice (green, C). (A,B,C) Typical time courses of $\mathrm{mI}_{\mathrm{CAT}}$ evoked by carbachol $(\mathrm{CCh}$, $100 \mu \mathrm{M}$ ) application (arrowhead) recorded at $-50 \mathrm{mV}$ (left panels) and steady state I-V relationships (right panels) are shown. (D) Density of carbachol (left) and GTP $\gamma$ S-induced $\mathrm{mI}_{\mathrm{CAT}}$ (right) at $-50 \mathrm{mV}$ and $+50 \mathrm{mV}$ in smooth muscle cells isolated from wild-type (black), $\mathrm{TRPC}^{-{ }^{--}}$(red), $\mathrm{TRPC}^{-{ }^{--}}$(blue) and TRPC4 $4^{-I-} / \mathrm{TRPC}^{-I-}$ mice (green). Current densities in cells isolated from knockout animals were significantly different from those in wild-type cells $* * \mathrm{p}<0,01 ; * * * \mathrm{p}<0,001$, and differed between each other with $\mathrm{p}<0,0085$ (n, number of cells). (E,F) TRPC $4 \alpha$ and TRPC $4 \beta(\mathbf{E})$ and TRPC6 (F) are detectable in ileal myocyte lysates from wild-type mice (wt) but not in the corresponding cells from TRPC-deficient mice. Loading controls: $\mathrm{CaV} \beta 3$ (E) and TRPC4 (F) protein expression. 
A $-50 \mathrm{mV}$

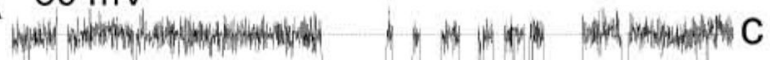<smiles>C1CCCC1</smiles><smiles>NCCNN</smiles>
$0.5 \mathrm{~s}$<smiles>[B]</smiles>
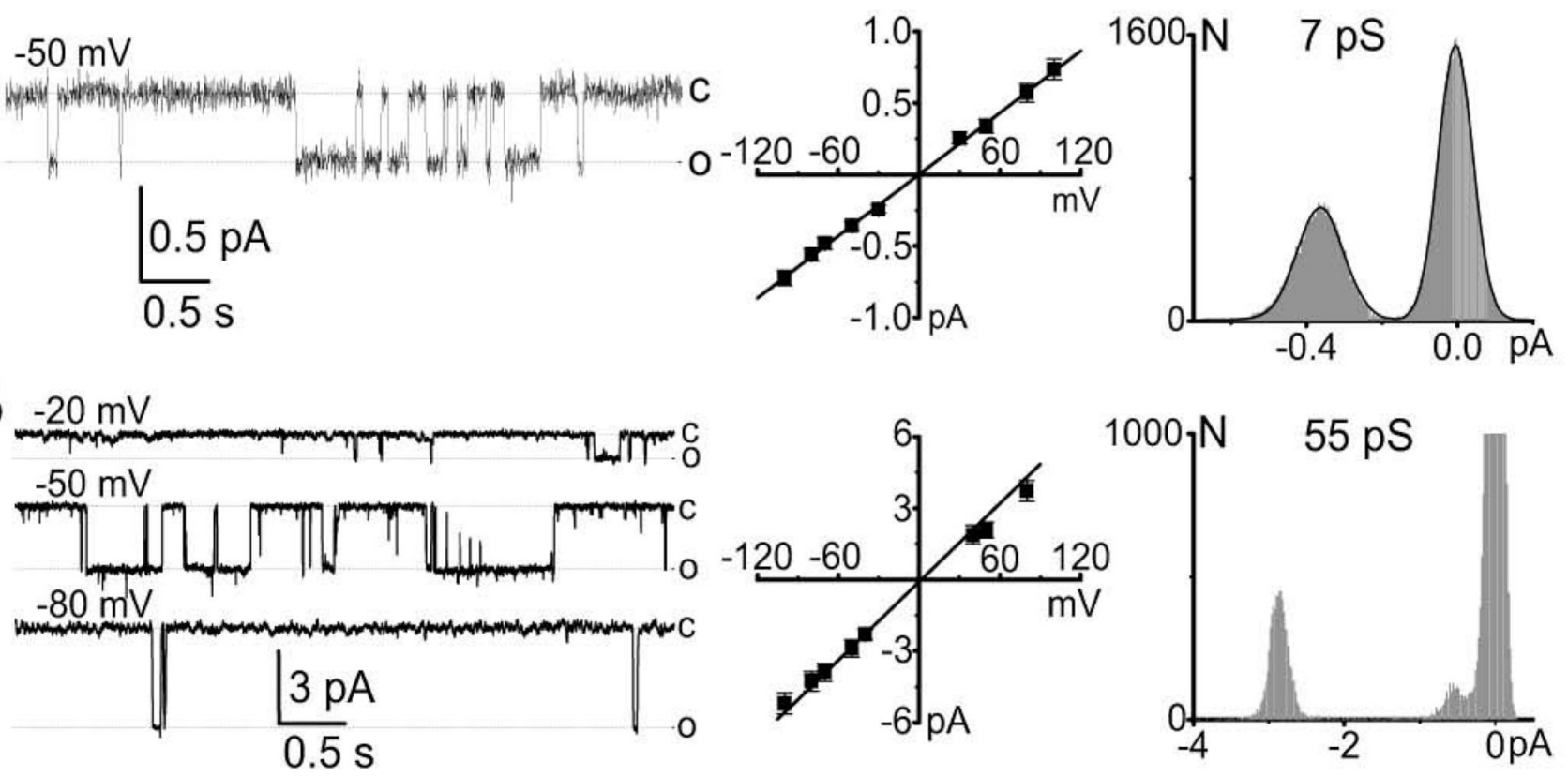

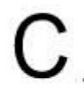

$-50 \mathrm{mV}$
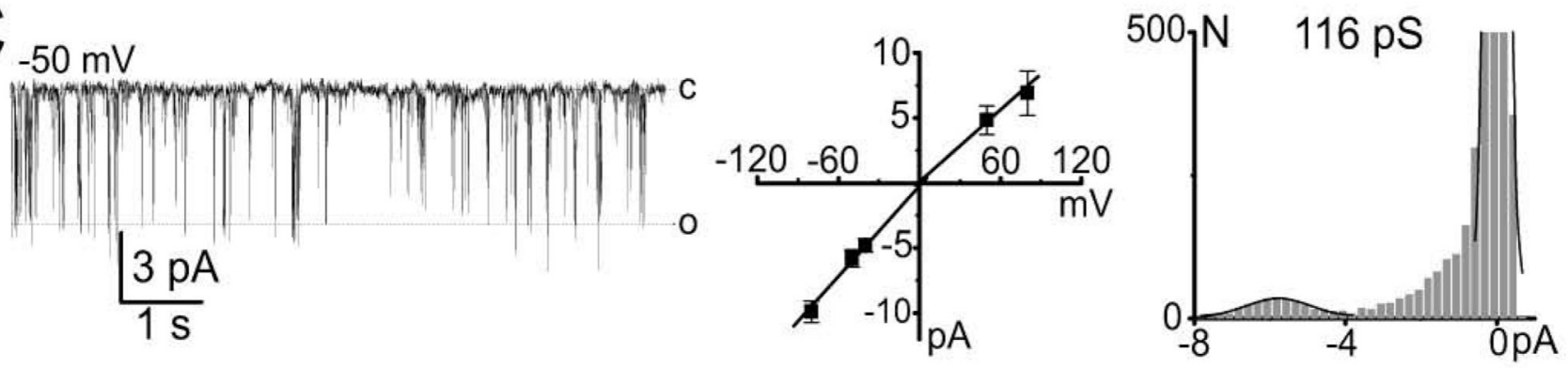

Figure 2. Single channel currents recorded from murine ileal myocytes in the presence of carbachol Single channel currents of $7 \mathrm{pS}(\mathbf{A}), 55 \mathrm{pS}(\mathbf{B})$ and $116 \mathrm{pS}(\mathbf{C})$ conductance cation channels recorded in the presence of carbachol $(100 \mu \mathrm{M})$ in outside-out patches. Examples of single channel current traces (left panels), corresponding I-V relationships (middle panels) and amplitude histograms of the records at $-50 \mathrm{mV}$ (right panels) are shown; the $7 \mathrm{pS}$ channel activity is also visible in panel $\mathrm{B}$. 

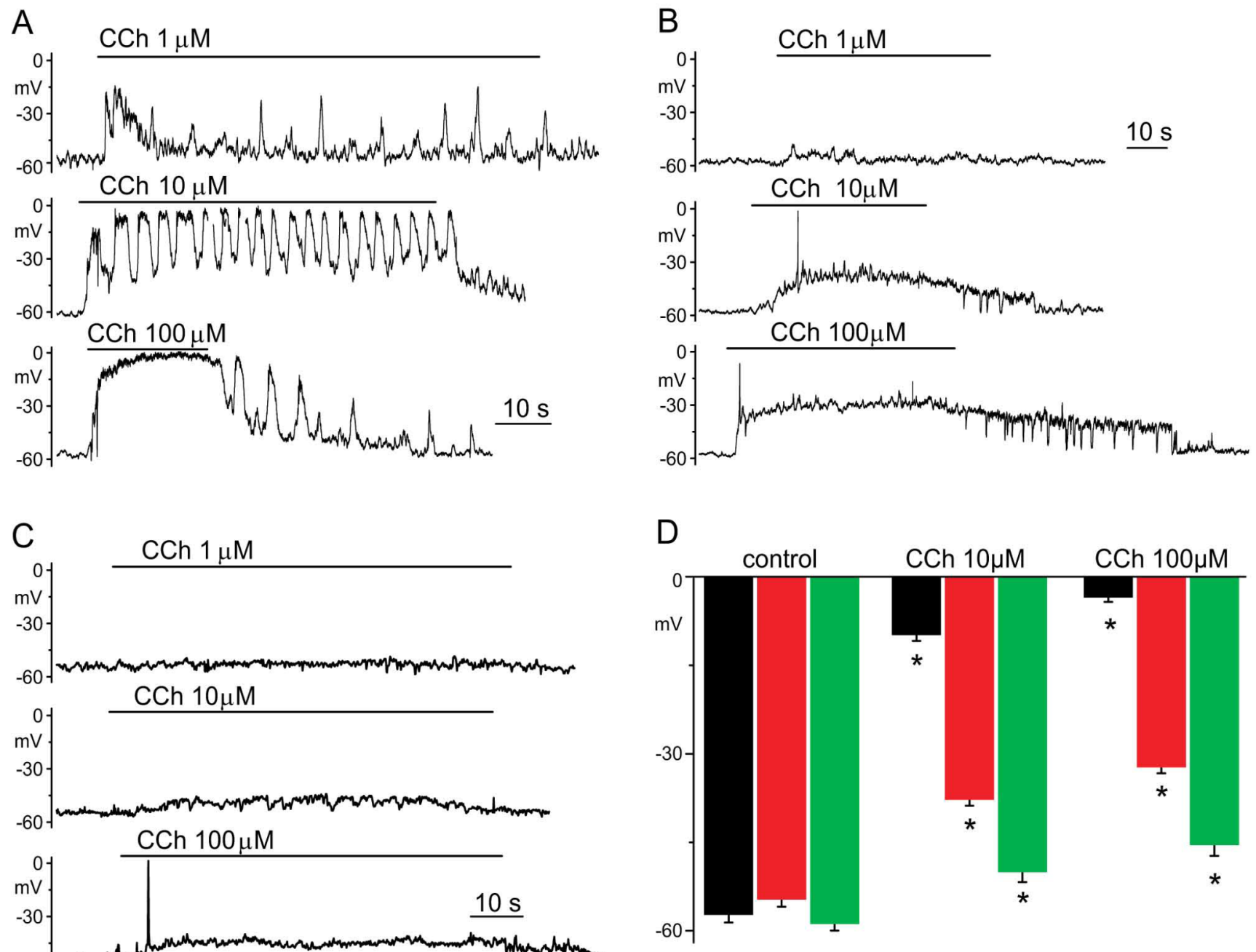

Figure 3. Carbachol-induced depolarization depends on TRPC4 and TRPC6 expression. (A, B) Representative examples of carbachol $(\mathrm{CCh}, 1,10,100 \mu \mathrm{M})$ induced changes of membrane potential in single smooth muscle cells recorded in whole-cell perforated patch mode from wild-type (A), TRPC4 $4^{-/-}$(B) and TRPC4 $4^{-/-} / \mathrm{TRPC}^{-1-}$ mice $(\mathbf{C})$. The presence of carbachol in the bath solution is indicated by bars. (D) Average resting membrane potential (control) and estimate of average maximal steady-state depolarization induced by carbachol at $10 \mu \mathrm{M}$ and $100 \mu \mathrm{M}$ in myocytes isolated from wild-type (black), $\mathrm{TRPC}^{-/-}$(red) and $\mathrm{TRPC}^{-/-}$/

TRPC6 $^{-1-}$ mice (green). Values in all tested groups were significantly different from the wild type control $(* * * \mathrm{p}<0,001$, ANOVA followed by Dunnet's Multiple Comparison and Tukey's Post Hoc test). 
A

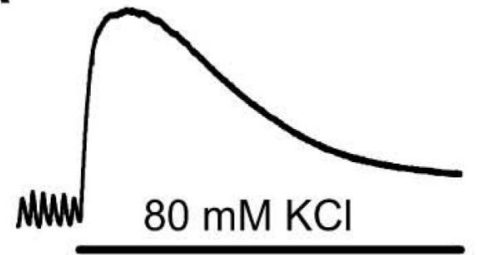

B

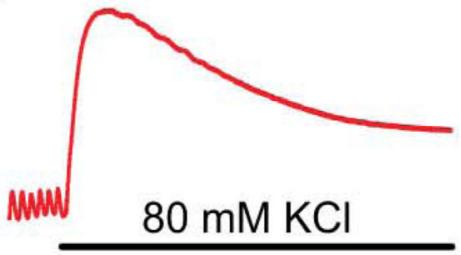

C

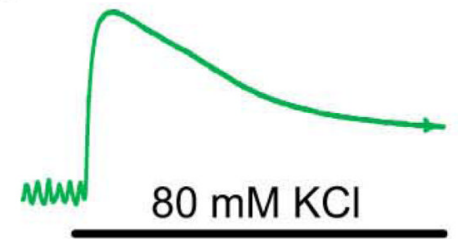<smiles>CC#Cc1c(C)ccc(C)c1C</smiles>
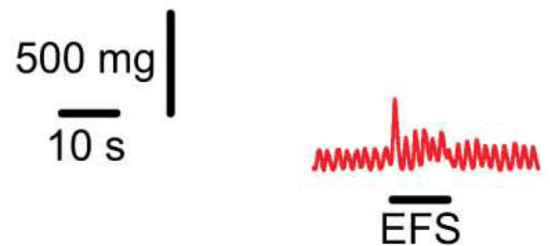

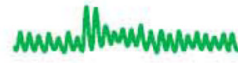

$\overline{\mathrm{EFS}}$
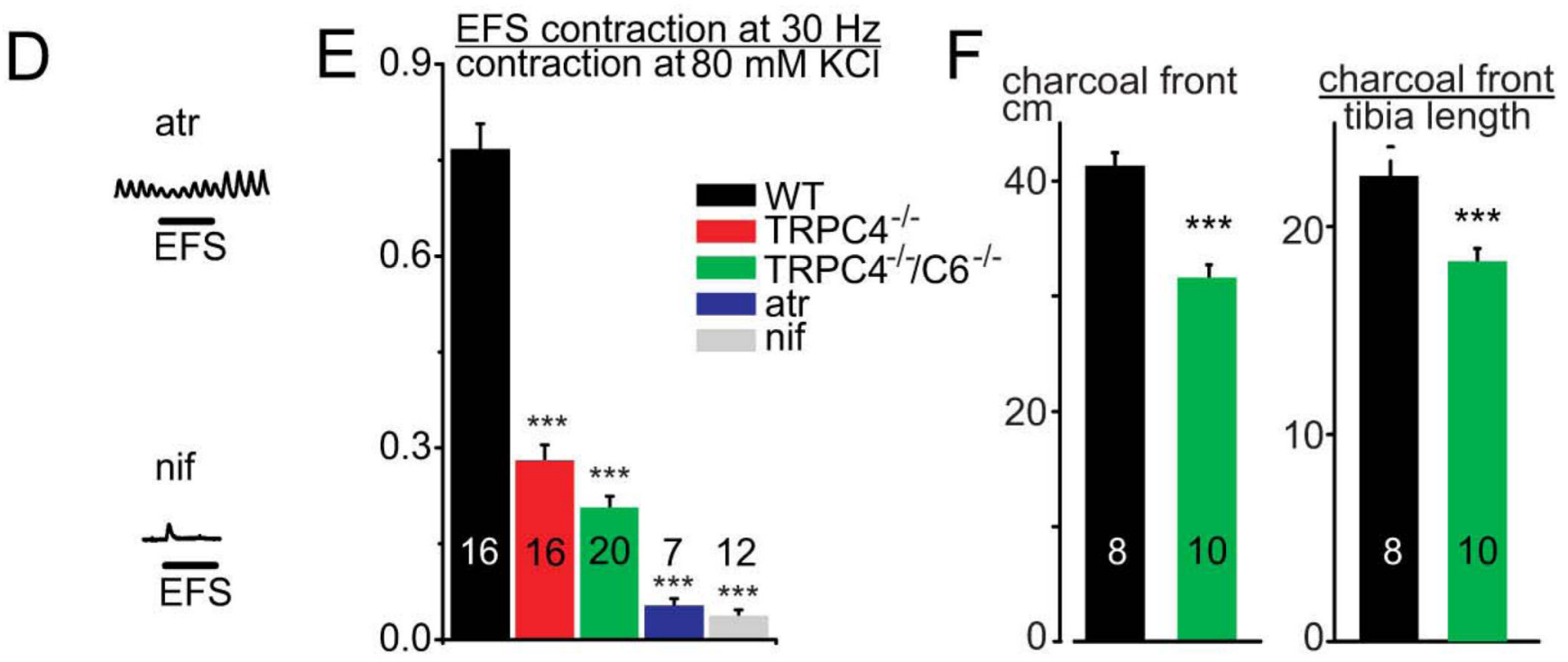

Figure 4. Reduced neurogenic contraction in $\mathrm{TRPC4}^{-/-}$and $\mathrm{TRPC4}^{-/-} / \mathrm{TRPC6}^{-/-}$ileal $^{-}$ longitudinal smooth muscle strips and reduced small intestinal transit Contraction of muscle strips from wild-type (black, A), TRPC4 ${ }^{-1-}$ (red, B) and TRPC4 ${ }^{-1-}$ / TRPC6 $^{-1-}$ mice (green, C) induced by $80 \mathrm{mM}$ potassium (upper panels) or EFS $(1 \mathrm{~ms}, 30 \mathrm{~Hz}$, lower panels). (D) EFS-induced contraction in the presence of atropine (atr, $1 \mu \mathrm{M}$; upper) or nifedipine (nif, $10 \mu \mathrm{M}$; lower). (E) Average EFS-induced neurogenic contraction of ileal strips from wild-type (black), TRPC4 ${ }^{-/-}$(red) and $\mathrm{TRPC}^{-/-} / \mathrm{TRPC}^{-/-}$mice (green), or ileal strips from wild-type mice in the presence of $1 \mu \mathrm{M}$ atropine (blue) or $10 \mu \mathrm{M}$ nifedipine (grey); numbers indicate independent smooth muscle strips. Values in all tested groups were significantly different from the wild-type control $(* * * \mathrm{p}<0,001$, ANOVA followed by Dunnet's Multiple Comparison). (F) Small intestinal transit of charcoal at $60 \mathrm{~min}$ after orogastric gavage expressed as the measured distance from the pyloric sphincter to the front of the charcoal stained area (left panel) normalized to tibia length (right panel). Black: Wild-type mice, $\mathrm{n}=8$; Green: TRPC4 ${ }^{-1-} / \mathrm{TRPC}^{-1-}$ mice; $\mathrm{n}=10$. 
A

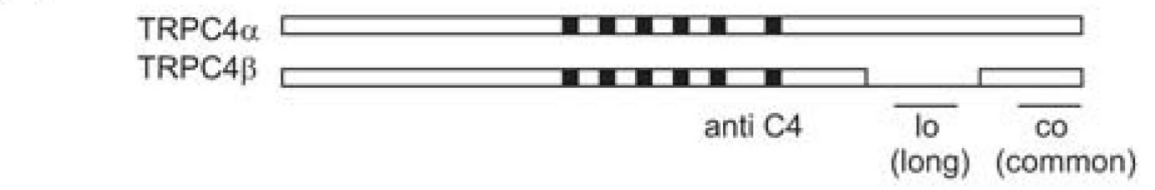

B

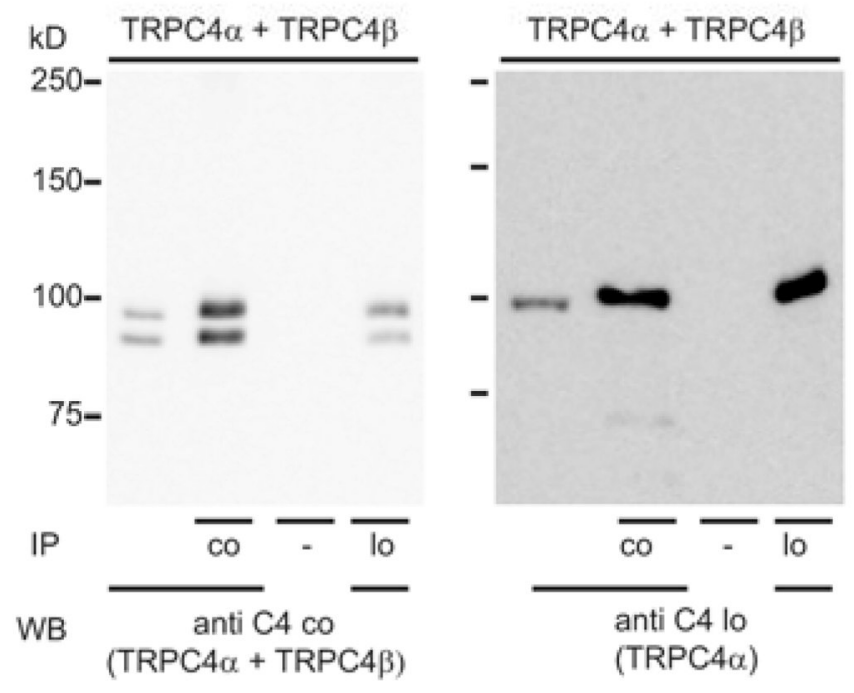

C

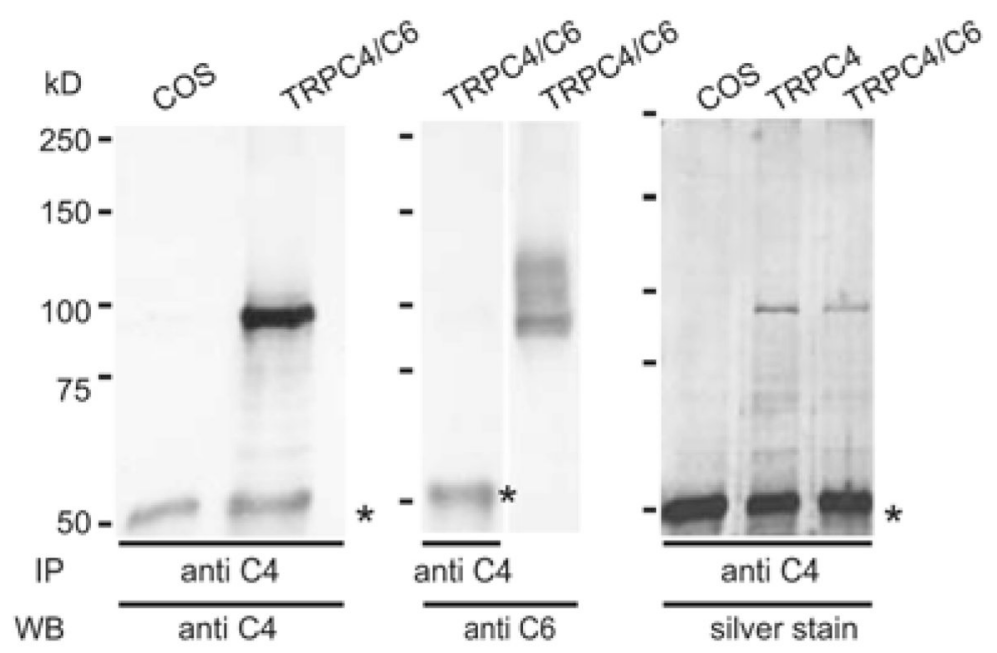

Figure 5. TRPC4 $\alpha$ coassembles with TRPC4 $\beta$ but not with TRPC6

(A) Domains which are recognized by the antibodies for TRPC4. The common (co) antibody reognizes both isoforms, TRPC $4 \alpha$ and TRPC $4 \beta$, the second antibody (lo, long) recognizes only TRPC $4 \alpha$. (B) Co-immunoprecipitation of TRPC $4 \alpha$ and TRPC4 $\beta$. Immunoblots (WB) and precipitants (IP) by the common antibody and by the antibody which recognizes only TRPC $4 \alpha$. Lane -, precipitants obtained in the absence of primary antibody. (C) TRPC6 does not co-immunoprecipitate with TRPC4. Silver stain and immunoblots (WB) of lysates and precipitants by TRPC4 antibody from non-transfected COS cells (COS), TRPC4 and TRPC4/ TRPC6 expressing COS cells. * indicates precipitating Ig. 


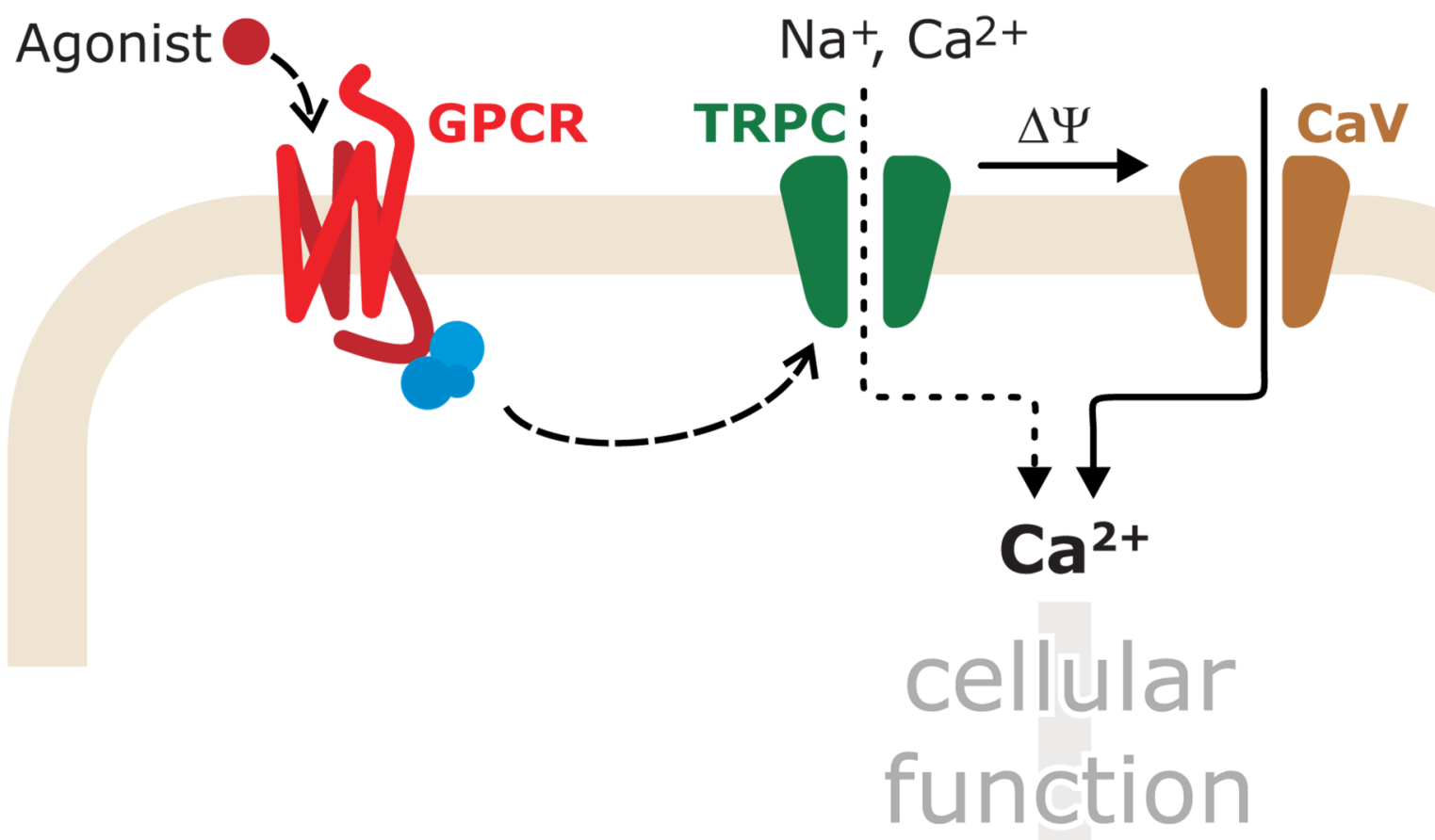

Figure 6. In ileal smooth muscle TRPC4 and TRPC6 (TRPC) channels couple the extracellular chemical signal acetylcholine (agonist) to membrane depolarization, $\mathrm{Ca}^{2+}$-influx and cell responses 